\title{
Research on the Relationship between CEO's Overconfidence and Corporate Investment Financing Behavior
}

\author{
Yan-liang Zhang*, Zi-wei Yang \\ Shandong University of Finance and Economics. Jinan P.R.China \\ E-mail:zhyanliang@sina.com (*Corresponding Author)
}

\begin{abstract}
At present, the classic corporate finance theory is challenged by various behavioral visions of corporate leaders in the actual decision-making of corporate finance. From the perspective of behavioral finance, this paper selects the data of A-share listed companies in China's Shanghai Stock Exchange and Shenzhen Stock Exchange in 2003-2016 to study the relationship between CEO's overconfidence and business operations. The study found that: Overconfidence CEOs will tend to increase the level of leverage, increase the number of loans, especially to increase the number of short-term loans; When the economic growth is faster, the listed company's CEO is more inclined to overconfidence; However, unlike the results of foreign studies, overconfident companies did not replace CEOs more frequently than non-overconfident companies, and did not increase the probability of bankruptcy. Finally, the CEO of a state-owned company does not appear to be more overconfident than the CEO of a private company.
\end{abstract}

Keywords: CEO; Overconfidence; Enterprise Management

\section{Introduction}

A large number of studies have shown that CEO's overconfidence has a major impact on the company's investment and financing decisions, company performance, and future development direction. Does an overconfident CEO have any advantages or disadvantages for company development? Since ROLL introduced this concept of overconfidence into the field of management for the first time in 1986, it has inspired scholars' enthusiasm. Early studies consistently agreed that managers generally have overconfidence, and overconfidence managers are prone to decision-making biases, which in turn threaten the healthy development of the company. Overconfident managers tend to conduct M\&A activities that reduce the value of the company and tend to overinvest or underinvest. Therefore, it is of utmost importance to study how CEO's overconfidence will affect the company. This article draws lessons from the research results of domestic and foreign scholars, using actual data to examine the relationship between CEO overconfidence and investment behavior and its impact on business performance.

\section{Review of literature}

To study the issues mentioned in this article, we must first pay attention to what factors will affect the CEO's overconfidence. Rao Yulei and Jia Wenjing [1] found that CEOs with long tenure tend to be overconfident; CEOs of listed companies with high risks in the industry are prone to overconfidence; and CEOs of companies with higher debt ratios tend to show overconfidence. The personal characteristics of the CEO have no influence on the level of overconfidence of the CEO, thus indicating that personal characteristics such as age, education level, and education level are not factors that influence the overconfidence of the CEO.

From the point of view of the CEO's overconfidence and corporate investment, the studies of Heaton [2] showed that the overconfidence of the company's senior executives will cause the company's profitability to decline. Malmendier and Tate [3] found that managers with overconfidence tend to make investment decisions based on the current state of the company's cash flow, and that they are positively related to the degree of overconfidence due to the financial status of the company, especially for those investing. Investment decisions are often influenced by the financial status of the company. Tan Chang [4] believes that executive overconfidence is significantly positively correlated with expansionary investment, while expansionary investment is significantly negatively correlated with corporate performance. This indicates that expansionary investment will reduce company performance.

From the point of view of CEO overconfidence and corporate finance, Landier and Thesmar [5] empirically tested the French listed companies in recent years and found that managers with overconfidence are more likely to choose to use short-term debt for financing. This is because overconfident managers tend to overestimate the company's operating capabilities and the expected benefits of the project. At the same time, they think that they 
can well raise the funds needed for the operation of the company, that is, if necessary, they can quickly withdraw funds to repay debts. In addition, they will also underestimate the payback period of investment projects, and therefore tend to choose short-term liabilities. Wang Jing [6] found through research that the overconfidence of the general manager and the chairman of the board of directors tend to prolong the period of debt, and at the same time, when the company's internal cash flow is abundant, the overconfident managers prefer internal financing.

\section{Hypothesis of research}

Hypothesis 1. Overconfidence CEOs tend to increase the number of loans

In general, an overconfident CEO will overestimate the future benefits of the investment project and underestimate the risk of the project. As a result, projects that inevitably result in a large number of negative NPV are also invested. Therefore, overconfident CEOs tend to increase the number of loans.

Hypothesis 2. Overconfident CEOs tend to issue short-term loans instead of long-term loans

First of all, overconfident CEOs often believe that their business capabilities are stronger than others, and overestimate the future earnings of investment projects, so they will be more inclined to choose short-term debt financing. Second, overconfident managers tend to think that they can well raise the funds needed for the operation of the company, that is, if necessary, they can quickly return funds to repay their debts.

Hypothesis 3. Overconfidence firms tend to have higher leverage than non-overconfident firms

The CEO's overconfidence has an impact on corporate finance policies. When overconfident CEOs overestimate the return on investment but cannot fully invest with their own capital, they need to borrow external funds and they are more willing to convert the debt into equity [7].

Hypothesis 4. The listed company CEO is more inclined to overconfidence when the economic growth is faster

When the economic situation is very good, the company's financial situation is good and the company is operating normally. The CEO has reason to believe that his business ability is stronger than other companies, and overestimates the future earnings of investment projects, which makes them anticipate the profitability of future projects is good. The CEO of a listed company will be more inclined to show overconfidence and show up by increasing its holdings of company stocks.

\section{Data processing}

\subsection{Sources of data}

In order to test whether the above assumptions are true, this paper selects listed companies in Chinese A-share market of Shanghai and Shenzhen Stock Exchange as samples, and the research interval is 2003-2016. Taking into account the special nature of financial companies and financial data are quite different from other industries, this article excludes financial listed companies. However, unlike previous studies, this article retains ST listed companies and treats ST and ST* listed companies as dummy variables to examine whether there is a significant causal relationship between CEO's overconfidence and company's poor management. All the financial data and corporate governance data of the sample company are from CSMAR series research database. The Shanghai A- share index is derived from Wind database.

\subsection{Measurement of overconfidence}

This article uses two methods to measure the CEO's overconfidence. The first method is that if the CEO has never reduced the stock of the company during his tenure, that is to say, the number of shares of the CEO is unchanged or increased, then we define this type of CEO as overconfidence. The second method is that we add a restriction condition based on method one. If the company's stock price growth rate is smaller than the growth rate of the broader market, the CEO holds the company's stock or stays the same, then thinks that the CEO has overconfidence. The following conditions are satisfied:

(1) Hold $_{\mathrm{i}}$ Hold $_{\mathrm{i}-1} \geq 0$

(2) Price $_{\mathrm{i}} /$ Price $_{\mathrm{i}-1}<$ Index $_{\mathrm{i}} /$ Index $_{\mathrm{i}-1}$

If these two conditions are established at the same time, it is considered that the company's CEO is overconfident. Among them, Hold $\mathrm{i}_{\mathrm{i}}$ is the number of shares of the company held by the CEO at the end of year $\mathrm{i}$, Price $_{i}$ is the closing price of the company's shares at the end of year $i$, and Index $\mathrm{i}_{i}$ is the Shanghai Stock Exchange A-Share Index at the end of year i.

\subsection{Sources and definitions of variables}


Table 1 Sources and definitions of variables

\begin{tabular}{l|l|l}
\hline \hline Variable type & variable name & Variable source \\
\hline \multirow{5}{*}{ Explained variable } & Short & CSMAR database \\
\cline { 2 - 3 } & T_loans & CSMAR database \\
\cline { 2 - 3 } & C_L_loans & CSMAR database \\
\cline { 2 - 3 } & leverage & CSMAR database \\
\cline { 2 - 3 } & Market_leverage & CSMAR database \\
\cline { 2 - 3 } & Book_leverage & CSMAR database \\
\hline \multirow{5}{*}{ Explanatory variables } & T_assets & CSMAR database \\
\cline { 2 - 3 } & Book_leverage & CSMAR database \\
\cline { 2 - 3 } & ROA & CSMAR database \\
\cline { 2 - 3 } & Debt_assets_ratio & CSMAR database \\
\hline & OC1 & CSMAR database \\
\cline { 2 - 3 } & OC2 & CSMAR database \\
\cline { 2 - 3 } & TURNOVER & CSMAR database \\
\cline { 2 - 3 } & ST & CSMAR database \\
\cline { 2 - 3 } & Control & CSMAR database \\
\cline { 2 - 3 } & OC_GDP & \\
\hline \hline
\end{tabular}

\section{Analysis of measurement results}

\subsection{Descriptive statistics}

Table 2 Descriptive statistics

\begin{tabular}{lcccccc}
\hline variable & $\mathrm{N}$ & $\mathrm{m} e a n$ & $\mathrm{sd}$ & $\mathrm{p} 25$ & $\mathrm{p} 50$ & $\mathrm{p} 75$ \\
\hline Short & 19926 & 0.260 & 0.220 & 0.0500 & 0.230 & 0.410 \\
T loans & 19928 & $3.800 \mathrm{e}+09$ & $1.600 \mathrm{e}+10$ & $3.500 \mathrm{e}+08$ & $9.000 \mathrm{e}+08$ & $2.400 \mathrm{e}+09$ \\
C L loans & 17019 & 0.0100 & 0.0200 & 0 & 0.0100 & 0.0100 \\
leverage & 19926 & 3.430 & 6.160 & 1.600 & 2.170 & 3.400 \\
Market lev e & 19926 & 0.430 & 6.430 & 0.380 & 0.540 & 0.710 \\
Book lever e & 19928 & 8.350 & 6.650 & 4.470 & 6.750 & 10.14 \\
T assets & 19928 & $6.400 \mathrm{e}+09$ & $2.200 \mathrm{e}+10$ & $1.100 \mathrm{e}+09$ & $2.100 \mathrm{e}+09$ & $4.700 \mathrm{e}+09$ \\
ROA & 19925 & -0.0400 & 16.14 & 0.0100 & 0.0300 & 0.0600 \\
Debt asset O & 19926 & 0.570 & 6.430 & 0.290 & 0.460 & 0.620 \\
OC1 & 20024 & 0.330 & 0.470 & 0 & 0 & 1 \\
OC2 & 20024 & 0.360 & 0.480 & 0 & 0 & 1 \\
TURNOVER & 20024 & 0.0600 & 0.240 & 0 & 0 & 0 \\
ST & 20024 & 0.0400 & 0.200 & 0 & 0 & 0 \\
Control & 20024 & 0.500 & 0.500 & 0 & 0 & 1 \\
OC GDP & 19928 & 0.400 & 0.490 & 0 & 0 & 1 \\
\hline
\end{tabular}

\subsection{The effect of CEO overconfidence on corporate loans and leverage}

The first econometric model was designed to measure the effect of CEO overconfidence on corporate lending and leverage. We use multiple regression models for analysis to explain the influence of overconfidence of CEOs of Chinese A-share listed companies on business operations. We have designed an econometric model as follows:

Annual_Rate $=\alpha+\beta_{10 C}+\beta_{2 Z}+V_{i}+\mu_{t}+\epsilon$

In this formula, the dependent variable Annual_Rate represents six independent variables, namely, the company's short-term loan rate, total loans, change rate of total loans, leverage, book leverage, and market leverage; $\mathrm{OC}$ is a dummy variable. If the business is overconfident, $\mathrm{OC}$ equals 1 , otherwise zero. $\mathrm{Z}$ is the 
characteristics of the company's assets, including total assets, book leverage, return on assets, asset-liability ratio, and fixed effects representing the bank and the year respectively, representing random errors.

The regression analysis of CEO's overconfidence and corporate loan relationship is as follows:

Table 3 CEO's overconfidence and corporate loans

\begin{tabular}{|c|c|c|c|c|c|}
\hline & (1) & (2) & (3) & (4) & (5) \\
\hline & Short_loans & Short_loans & C_loans & C_loans & T_loans \\
\hline \multirow[t]{2}{*}{ OC1 } & $0.0114 * * *$ & & $0.00277 * * *$ & & $436690619.3 * *$ \\
\hline & $(2.75)$ & & $(6.29)$ & & $(2.05)$ \\
\hline \multirow[t]{2}{*}{$\mathrm{OC} 2$} & & $0.0259 * * *$ & & $0.00292 * * *$ & \\
\hline & & $(5.98)$ & & $(6.84)$ & \\
\hline \multirow[t]{2}{*}{ _cons } & $0.251 * * *$ & $0.246 * * *$ & $0.00776 * * *$ & $0.00755^{* * *}$ & $3.64627 \mathrm{e}+09 * * *$ \\
\hline & $(146.55)$ & (129.59) & $(29.72)$ & $(27.91)$ & (41.36) \\
\hline $\mathrm{N}$ & 19926 & 19926 & 17019 & 17019 & 19928 \\
\hline
\end{tabular}

Note: $*$, **, and $* * *$ indicate the significance levels of $5 \%, 1 \%$, and $0.1 \%$, respectively

Table 4 CEO's overconfidence and corporate loans

\begin{tabular}{|c|c|c|c|c|c|}
\hline & (6) & (7) & (8) & (9) & (10) \\
\hline & Short_loans & Short_loans & C_loans & C_loans & T_loans \\
\hline \multirow[t]{2}{*}{$\mathrm{OC} 1$} & $0.0120 * * *$ & & $0.00243^{* * *}$ & & $330549790.3 *$ \\
\hline & $(2.91)$ & & $(5.57)$ & & $(1.66)$ \\
\hline \multirow[t]{2}{*}{ T_assets } & $-4.13 \mathrm{e}-13 * * *$ & $-4.20 \mathrm{e}-13 * * *$ & $-4.50 \mathrm{e}-14 * * *$ & $-4.36 \mathrm{e}-14 * * *$ & \\
\hline & $(-3.45)$ & $(-3.51)$ & $(-4.44)$ & $(-4.32)$ & \\
\hline \multirow[t]{2}{*}{ Book_lever } & $-0.00170 * * *$ & $-0.00165 * * *$ & $0.000576 * * *$ & $0.000580 * * *$ & $635024902.5^{* * *}$ \\
\hline & $(-6.11)$ & $(-5.93)$ & $(18.00)$ & $(18.21)$ & (51.08) \\
\hline \multirow[t]{2}{*}{ ROA } & $-0.000297 * *$ & $-0.000299 * *$ & $-0.0000796 * * *$ & $-0.0000786^{* * *}$ & 6917251.2 \\
\hline & $(-2.08)$ & $(-2.09)$ & $(-3.73)$ & $(-3.69)$ & $(1.01)$ \\
\hline \multirow[t]{2}{*}{ Debt_assets } & -0.000294 & -0.000299 & $-0.000233 * * *$ & $-0.000230 * * *$ & 21149927.6 \\
\hline & $(-0.81)$ & $(-0.82)$ & $(-4.33)$ & $(-4.28)$ & $(1.21)$ \\
\hline \multirow[t]{2}{*}{$\mathrm{OC} 2$} & & $0.0254 * * *$ & & $0.00287 * * *$ & \\
\hline & & $(5.89)$ & & $(6.79)$ & \\
\hline \multirow[t]{2}{*}{ _cons } & $0.268 * * *$ & $0.263 * * *$ & $0.00354 * * *$ & $0.00319 * * *$ & $-1.63367 \mathrm{e}+09 * * *$ \\
\hline & (97.27) & $(90.20)$ & $(9.83)$ & $(8.61)$ & $(-12.34)$ \\
\hline $\mathrm{N}$ & 19924 & 19924 & 17017 & 17017 & 19925 \\
\hline
\end{tabular}

Note: $*, * *$, and $* * *$ indicate the significance levels of $5 \%, 1 \%$, and $0.1 \%$, respectively

The main results are shown in Table 1 and Table 2. For each dependent variable, we measure the CEO's overconfidence effect from two aspects. The first aspect includes only the CEO's overconfidence variables, and the second aspect adds control over the bank's characteristics. In order to save space, we do not report the year dummy variable in the analysis. In all models, our regression includes all available non-financial listed companies' available data.

By comparing the two overconfidence variables $\mathrm{OC} 1$ and $\mathrm{OC} 2$, it is not difficult to find that $\mathrm{OC} 2$ has a larger $\mathrm{t}$ value than $\mathrm{OC} 1$, which indicates that the second defined overconfidence variable has a more significant regression result. This is theoretically in line with expectations, because the second definition of overconfidence is to add a constraint under the first definition. It must be met if the CEO's stock returns are lower than the market returns. Reduce the company's stock condition. This also shows on one side that it is more valuable to use OC2 to define overconfidence and that the defined overconfidence CEO is more targeted.

To further study our hypothesis, we used different types of leverage as the dependent variables to study the relationship between CEO overconfidence and corporate leverage. The results of the regression are shown in Table 3. 
Table 5 CEO's overconfidence and corporate leverage

\begin{tabular}{|c|c|c|c|c|c|c|}
\hline & (1) & (2) & (3) & (4) & (5) & (6) \\
\hline & Market_leverage & Market_leverage & Book_leverage & Book_leverage & leverage & leverage \\
\hline \multirow[t]{2}{*}{$\mathrm{OC} 2$} & $0.235 * *$ & -0.000215 & & & $0.739 * * *$ & $0.744 * * *$ \\
\hline & $(2.48)$ & $(-0.61)$ & & & $(6.37)$ & $(6.47)$ \\
\hline \multirow[t]{2}{*}{ T_assets } & & $7.49 \mathrm{e}-17$ & & $1.27 \mathrm{e}-10 * * *$ & & $-9.38 \mathrm{e}-12 * * *$ \\
\hline & & $(0.01)$ & & $(50.14)$ & & $(-3.56)$ \\
\hline \multirow[t]{2}{*}{ Book_lever } & & -0.0000222 & & & & $-0.0526 * * *$ \\
\hline & & $(-0.82)$ & & & & $(-6.55)$ \\
\hline \multirow[t]{2}{*}{ ROA } & & -0.0000114 & & -0.00426 & & $-0.0157 * * *$ \\
\hline & & $(-0.54)$ & & $(-1.09)$ & & $(-3.16)$ \\
\hline \multirow[t]{2}{*}{ Debt_assets } & & $-1.000 * * *$ & & -0.0162 & & $-0.0474 * * *$ \\
\hline & & $(-18883.69)$ & & $(-1.63)$ & & $(-3.76)$ \\
\hline \multirow[t]{2}{*}{$\mathrm{OC} 1$} & & & $0.293 *$ & $0.229 * *$ & & \\
\hline & & & $(2.64)$ & $(2.18)$ & & \\
\hline \multirow[t]{2}{*}{ _cons } & $0.348 * * *$ & $1.000 * * *$ & $8.375^{* * *}$ & $7.632 * * *$ & $3.518 * * *$ & $4.035 * * *$ \\
\hline & $(6.09)$ & (3294.97) & $(66.20)$ & $(61.52)$ & (40.03) & $(37.32)$ \\
\hline $\mathrm{N}$ & 19926 & 19925 & 19928 & 19925 & 19926 & 19924 \\
\hline
\end{tabular}

Note: $*, * *$, and $* * *$ indicate the significance levels of $5 \%, 1 \%$, and $0.1 \%$, Respectively

We found that the coefficient of OC in model 2 is negative, and the absolute value of the coefficient is very small and not significant. We can think that this is because the influence of other factors on market leverage has weakened the influence of OC. In addition to model 2, it can be seen that the coefficient of OC is always significantly positive regardless of the type of leverage used, and is statistically significant at $5 \%$ or better. For example, a coefficient of 0.235 for Model 1 suggests that the average annual market leverage rate of overconfidence firms is $23.5 \%$ higher than that of non-overconfident firms, which is statistically significant and provides sufficient evidence to support Hypothesis 3. (Overconfident companies often have higher leverage than non-overconfident companies.)

\subsection{Endogenousissues}

The impact of CEO overconfidence on corporate lending and leverage may lead to endogenous problems. Therefore, in Table 6, we use a 2SLS corporate regression model to determine whether the regression results are endogenously robust.

For such a 2SLS regression analysis, the most important thing is to find a good external tool variable. This variable is economically related to the overconfidence of the CEO, but it is not related to the error items related to the loans and leverage regression of the silver enterprise.

To find such a tool, we considered a variable that has been shown in the literature on overconfidence as a determinant of CEO overconfidence: CEO's age.

Bruin, Parker and Fischhoff [8] believe that the relationship between age and overconfidence is significant. In senior jobs such as the company's CEO position, they believe that older people tend to be more overconfident than young people. Similarly, Crawford and Stankov [9] also found that older people showed greater overconfidence than young people. Therefore, we believe that the CEO's age is positively related to the CEO's overconfidence. We also have no reason to believe that the instrument has a direct economic impact on corporate loans and leverage, so it is unlikely that the instrument will be related to the error term in the second phase of the regression.

In the 2SLS model, we see the OC as an endogenous variable that interacts with CEO age in the first stage.

Stage 1: Regressing instrument variables and other exogenous variables of the model to OC

$$
\mathrm{P}(\mathrm{OC} \mid \mathrm{CEO} \text { Age, } \mathrm{Z})=\mathrm{L}\left(\delta 1+\delta 2 \mathrm{CEO} \mathrm{Ag} \mathrm{e}+\theta \mathrm{Z}+\mathrm{V}_{\mathrm{i}}+\mu_{\mathrm{t}}\right)
$$

Stage 2: In the main regression equation, use OC's fitting value OC3 instead

$$
\text { Annual Rate }=\alpha+\beta_{10 C 3}+\beta_{2 Z}+V_{i}+\mu_{t}+\epsilon
$$

In this formula, the dependent variable Annual_Rate represents six independent variables, which are the company's short-term loan rate, total loans, change rate of total loans, leverage, book leverage, and market 
leverage; OC is a dummy variable if the company is excessive Self-confident, OC is equal to 1, otherwise it is zero, OC3 is the predicted value of OC generated in the first stage regression, and CEO Age is the CEO's age. Z is the characteristics of the company's assets, including total assets, book leverage, return on assets, asset-liability ratio, and fixed effects representing the bank and the year respectively, representing random errors. The regression results are shown in Table 6, in parentheses based on robust standard errors for heteroskedastic adjustments [10]. *,**, and *** indicate significance at 10\%, 5\%, and $1 \%$ levels, respectively.

Table 6 Effect of CEO overconfidence on corporate loans and leverage under 2SLS model analysis

\begin{tabular}{|c|c|c|c|c|c|c|c|}
\hline \multirow[t]{2}{*}{ stage } & First & Second & Second & Second & Second & Second & Second \\
\hline & $\mathrm{OC} 2$ & C_L_loans & leverage & Book_leverage & Market_leverage & Short & T_loans \\
\hline \multirow[t]{2}{*}{ age } & $0.00438 * * *$ & $\begin{array}{l}-0.000395 * * \\
*\end{array}$ & $-0.0843 * * *$ & $-1.014 * * *$ & $-1.098 * * *$ & $-0.00125^{* *}$ & -9385493.5 \\
\hline & $(8.37)$ & $(-6.01)$ & $(-5.16)$ & $(-91.10)$ & $(-17073.61)$ & $(-2.17)$ & $(-1.22)$ \\
\hline \multirow[t]{2}{*}{ T_assets } & $-6.49 \mathrm{e}-13 * * *$ & $5.92 \mathrm{e}-15$ & $3.62 \mathrm{e}-12$ & $2.15 \mathrm{e}-10 * * *$ & $1.63 \mathrm{e}-10 * * *$ & $\begin{array}{l}-7.02 \mathrm{e}-13 * * \\
*\end{array}$ & $0.713 * * *$ \\
\hline & $(-3.93)$ & $(0.47)$ & (1.19) & (110.23) & (13546.46) & $(-6.55)$ & $(495.27)$ \\
\hline \multirow{2}{*}{$\begin{array}{l}\text { Book_leve } \\
\mathrm{r}\end{array}$} & $0.00157 * * *$ & $0.000433 * * *$ & $-0.113 * * *$ & & $-0.393 * * *$ & $-0.000759 * *$ & $41407488.0 * * *$ \\
\hline & $(2.90)$ & (12.05) & $(-12.92)$ & & $(-11434.56)$ & $(-2.47)$ & (10.04) \\
\hline \multirow[t]{2}{*}{ ROA } & $-0.00128 * * *$ & -0.0000033 & -0.000562 & $-0.0215 * * *$ & $0.321 * * *$ & -0.000142 & 178617.6 \\
\hline & $(-3.04)$ & $(-0.31)$ & $(-0.21)$ & $(-9.82)$ & (30113.12) & $(-1.50)$ & $(0.14)$ \\
\hline \multirow{2}{*}{$\begin{array}{l}\text { Debt_asset } \\
\mathrm{s}\end{array}$} & $-0.00399 * * *$ & & & & & & \\
\hline & $(-3.78)$ & & & & & & \\
\hline \multirow[t]{2}{*}{ OC3 } & & $0.0630 * * *$ & $20.43 * * *$ & $236.9 * * *$ & $250.6 * * *$ & -0.0999 & $\begin{array}{l}-5.93609 \mathrm{e}+09 * \\
* *\end{array}$ \\
\hline & & $(4.73)$ & $(6.05)$ & (109.58) & (18875.73) & $(-0.84)$ & $(-3.73)$ \\
\hline \multirow[t]{2}{*}{ _cons } & $0.149 * * *$ & 0.000521 & 0.927 & $-31.04 * * *$ & $-36.36 * * *$ & $0.362 * * *$ & $\begin{array}{l}1.47161 \mathrm{e}+09 * * \\
*\end{array}$ \\
\hline & $(5.92)$ & $(0.22)$ & $(1.58)$ & $(-73.86)$ & $(-15803.88)$ & (17.60) & $(5.34)$ \\
\hline $\mathrm{N}$ & 19901 & 16997 & 19900 & 19901 & 19901 & 19900 & 19901 \\
\hline
\end{tabular}

Note: $* * *$, and $* * *$ indicate the significance levels of $5 \%, 1 \%$, and $0.1 \%$, respectively

As shown in the above table, the CEO's overconfidence is positively related to the year-on-year loan change rate (C_L_loans), corporate leverage, book leverage, and market leverage, and is highly significant. This also validates our hypothesis3 (overconfident companies often have higher leverage than non-overconfident companies).

In Models 1 and 2 above, the coefficients on OC are positive and statistically significant. This confirms Hypothesis 1 (in non-crisis years, overconfident companies make more aggressive loan decisions than non-overconfident companies). For example, after controlling the characteristics of the firm, the coefficient of OC3 in model 2 is 0.0630 , which indicates that during the crisis, the annual change rate of loans for overconfident companies was on average $6.3 \%$ higher than that of non-overconfident companies.

To further test our hypothesis 2, Model 3-5 uses different types of leverage as dependent variables. Regardless of the type of leverage, the coefficient of OC is significantly positive and is statistically significant at $5 \%$ or better. For example, in Model 3, the coefficient of OC indicates that overconfidence firms experienced an average of $20.43 \%$ leverage change rate over non-overconfident enterprises. This shows that overconfidence companies make more aggressive loan decisions than non-overconfident companies. In Model 4, OC's coefficient of 250.6 shows that overconfidence firms have an average annual market leverage of $250.6 \%$ higher than non-overconfident companies. This can provide evidence that overconfident companies tend to have higher leverage than non-overconfident companies.

These results generally support our first two assumptions: Overconfidence firms are more aggressive than non-overconfident firms. Overconfidence companies also have more leverage than non-overconfident companies.

\section{Conclusions}

This article examines the relationship between CEO overconfidence and corporate investment financing behavior. The results show that: Overconfidence CEOs will tend to increase their level of leverage, increase the 
number of loans, especially to increase the number of short-term loans; when the economic growth is faster, the CEO of listed companies tends to be overconfident. But different from the results of foreign studies, the overconfident companies did not change CEOs more frequently than non-overconfident companies, nor did they increase the probability of bankruptcy. Finally, the CEOs of state-owned companies did not appear to be more overconfident than the CEOs of private enterprises.

\section{Acknowledgements}

This is a phase achievement of Shandong Science and Technology Development Project which is "Research on the relationship between the listed company ownership structure and business performance 2011GGH12206".

\section{References}

[1]Rao Yulei, Jia Wenjing. Analysis of the Factors that Influence the CEO's Overconfidence. Chinese Journal of Management. 2011, (8): 1162-1167.

[2]Heaton J. Managerial Optimism and Corporate Finance. Financial Management. 2002.31(2):33-45.

[3]Malmendier,Tate. CEO Overconfidence and Corporate Investment. Journal of Finance, 2005,60(6):2661-2700.

[4]Tan Chang. Overconfidence of Executives in State-controlled Listed Companies and Expansion of Public Investment Performance. Hainan University, 2013

[5]Landier,Thesmar. Financial Contracting with Optimistic Entrepreneurs: Theory and Evidence. University of Chicago, Working Paper. 2005.

[6]Jing Wang. Empirical Research on the Influence of Managers' Overconfidence on Investment and Financing Decisions of Listed Companies . Nanjing University of Science and Technology, 2008

[7]Malmendier, U. , Tate, G. , Yan, J. , 2011. Overconfidence and Early-life Experiences: the Effect of Managerial Traits on Corporate Financial Policies. Journal of Finance 66, 1687-1733 .

[8]Bruin, W. , Parker, A. , Fischhoff, B. , 2012. Explaining Adult Age Differences in Decision-Making Competence. Journal of Behavioral Decision Making 25, 352-360 .

[9]Crawford, J.D. , Stankov, L. , 1996. Age Differences in the Realism of Confidence Judgments: a Calibration Study Using Tests of Fluid and Crystallized Intelligence. Learning and Individual Differences 8, 83-103 .

[10]White, H. , 1980. A Heteroskedasticity-Consistent Covariance Matrix Estimator and a Direct Test for Heteroskedasticity. Econometrica 48, 817-838 . 